\title{
A Study on Perception of Business Students on the Future Job Market: A Case Study of Umma University.
}

\author{
Salah Abdirahman Farah, Hussein Abdi Ali \\ Lecturer, Garissa Teachers Training College and part-time lecturer Umma University, Kenya \\ Lecturer Umma University, Kenya
}

\begin{abstract}
The perception of future country's labor is important to be studied. The way they perceive the market in general and their future employers in particular cannot be wished away. The world has become very dynamic and so the employers. The needs of the market changes with the influence of so many factors among them the dynamism of technology. Students join courses they perceive important for them in one way or the other. One major factor why the youth pursue courses is to benefit out of it through gainful employment. Employers on the other hand are complaining about universities churning out half-baked graduates that can hardly cope with the stringent needs of the market. That the graduates are not productive and what they have being trained on is not relevant to the needs of specific jobs. This has led to many employers organizing short trainings for their new recruits.

In light of the above, the study sought to understand the perception of business students towards the future job market. It found out that close to two-thirds of business students have high expectations in terms of salaries and other benefits. This makes business courses being pursued by many students. Very few of the students have less expectations. More than half of the respondents are for the opinion that they will get a job during their first six months of graduation. High grades, good communication skills and having confidence are the major preferences of employers according to the research. The major causes of unemployment among the youth are lack of creation of job opportunities which has led to tribalism and nepotism in employment. This has locked out many qualified job seekers. Majority of business students prefer searching for a job rather than creating job opportunities themselves. A lot has to be done in order to streamline the courses offered by universities in order to cater for the needs of the market. There should be creation of awareness among the youth so that they prepare themselves for these needs. With these, both the students and their future employers will benefit and hence greater productivity.
\end{abstract}

Keywords(perception, market needs, expectations, employment, awareness)

\section{Introduction}

Many students join universities unaware of what is waiting for them in the future job market. In the span of four years for undergraduate, 18 months for diploma and 6 months for certificate students, they are exposed to various information, grapevine and half-baked stories emanating from the market. Students' joining universities have also increased dramatically. This is caused by high transition rates from high school to universities and improved accessibility among other factors. Reports have it that employers are not happy about the churning of half-baked students and irrelevant courses offered at our universities. They argue that these are major causes of unproductivity among these graduates.

This study therefore was conducted to understand the exact perception and attitudes of business students in the future job market. It was conducted at Umma University, Garissa learning center, Kenya. The institution is a private University in Kenya. It has campuses in Thika and Kajiado. It has recently conducted its first graduation ceremony where over 800 students were conferred with degrees, diplomas and certificates. It has a department of business management where students enroll for degrees, diplomas and certificates. The study focused specifically on business students. The research engaged 75 students doing business courses at 
various levels. A well prepared questionnaire was presented to the students where their responses were kept confidential. Gender, age and level of study were considered in the research. The objectives of the study were to understand Students' opinion on the starting salary scale for business graduates, Perception of students' towards duration of stay after graduation, their opinion on employers preference, causes of unemployment among business students in Kenya and perception of business students' engaging in selfemployment

\section{Literature Review}

A study by Teo poon (1994) researched about the perceptions of students studying business towards establishing small business after studies or working for Multinational companies. The research found out that MNCs were rated favorable compared to establishing a small business enterprises. The factors that favored the MNCs included pay, working conditions, long term career prospects, marketability, fringe benefits and job security. Establishing of these small businesses rated lower than in seeking jobs in MNCs among business students. The research also indicated that male and female students' perceptions of these two were absolutely similar among the ten job factors. Additionally, both gender perceived MNCs more favorable compared to self- employment.

Pascarella and Terenzini (1990) discovered a small yet consistent body of research "suggesting that the quality of effort or involvement students make in meeting the requirements of their formal academic program has an impact on their self-ratings of growth in career-related competencies and skills" it says that the quality of training and meeting of requirements of the job market impact on their future career. It concludes that for students to be absorbed in the job market easily, they should be prepared at the university level by enhancing quality of training.

Tagg (2003) has also identified similarity in relevance of getting experience in obtaining a job by fronting for the value of students taking an important and active role in their education by connecting what they have learnt to the job market. This connection puts high responsibility on the future worker by preparing them while studying. Learning becomes a process where students depend on their own personal perspectives when they want to decide what to engage in future endeavors in terms of self-employment or seeking employment. Students should be prepared as they have negative attitudes towards the future job market. It is only at the university where such kind of preparation can be enhanced.

Hillary Tomu (2013) studied the comparison of races on how they view future job market. His findings concluded that black students are more confident than whites that their degree will guarantee future employment. This could be because of policies like affirmative action enacted by the government. This was to bring previously disadvantaged groups on board, thus giving them first preference in the job market.

He also concluded that female students are more confident than the male counterparts about employment prospects. This is attributed to gender related affirmative actions that gives preference in the market to address imbalances. Black students are found to be less likely to experience hopelessness than the white who are non-beneficiaries of employment policies

\section{Methodology}

\section{Sampling}

Sampling is a vital step in data gathering. It is concerned with the selection of observation with the objective of obtaining a well-planned conclusion. It helps in achieving objectives set for a research. 75 students were carefully selected for this study. Sex, age, level of study and experience were the important parameters considered in the sample selection.

\section{Sources of Data Collection}

a) Primary sources:

A well planned and structured questionnaire was presented to the sample selected. Data confidentiality well considered.

b) Secondary sources: 
Relevant information from past records, newspapers, journals, articles and booklets were collected and reviewed.

\section{Tools and Techniques for Data Collection.}

Observation, interviews and questionnaire were the main tools used for collecting data. Relevant books, periodicals, reports and articles which were seen vital for the research were studied and reviewed.

\section{Plan of Analysis}

Tabulation was done on the data obtained. Corresponding percentages were also given. Bar graphs and pie charts were used for analysis and to get accurate interpretation. Wrong, dishonest and in accurate responses were discarded.

\section{Objectives of the study}

1. Students' opinion towards the starting salary scale for business graduates

2. Perception of students' towards duration of stay after graduation

3. Students opinion towards employers preference

4. Causes of unemployment among business students in Kenya

5. Perception of business students' engaging in self-employment

\section{Findings And Discussions}

1. Salary expectations

What is your salary expectations upon graduation?

\begin{tabular}{|l|l|l|}
\hline Responses(in Kenya shillings) & Frequency & Percentage \\
\hline Less than 10000 & 5 & 7 \\
\hline $10000-20000$ & 9 & 12 \\
\hline $20000-30000$ & 30 & 40 \\
\hline $30000-40000$ & 19 & 25 \\
\hline $40000-50000$ & 5 & 7 \\
\hline Above 50000 & 7 & 9 \\
\hline Total & $\mathbf{7 5}$ & $\mathbf{1 0 0}$ \\
\hline
\end{tabular}

Table 1: salary expectations

\section{Analysis}

Majority of the respondents said their salary expectations range between 20,000 and 40,000 Kenya shillings. This accounts for $65 \%$ of all the respondents. Only $7 \%$ said they expect less than a salary of 10,000 Kenya shillings. Those who said they expect to earn more than 50,000 Kenya shillings accounted for only $9 \%$.

NB/: Kshs/USD: $100.9278 / 101.1278$

What is your salary expectations upon graduation?

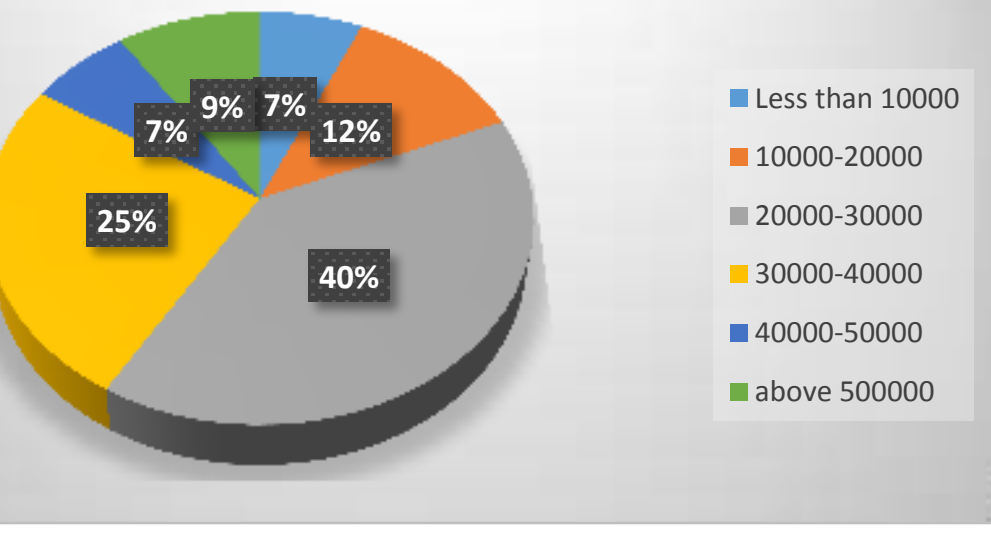




\section{Interpretations}

Business students' expectations in terms of salary is not badly off. This is probably why they have chosen to take up business courses. Close to two-thirds of business students have high expectations in terms of salaries and other benefits. This makes business courses being pursued by many students. Very few of the students have less expectations.

2. Duration of stay after graduation

What is your perception regarding employment time after graduation?

\begin{tabular}{|l|l|l|}
\hline Responses & Frequency & Percentage \\
\hline Immediately & 12 & 16 \\
\hline Less than 6 months & 29 & 39 \\
\hline Less than a year & 20 & 27 \\
\hline More than a year & 10 & 13 \\
\hline Never & 4 & 5 \\
\hline Total & $\mathbf{7 5}$ & $\mathbf{1 0 0}$ \\
\hline
\end{tabular}

Table 1: employment time after graduation

Analysis

When business students were presented to the question "What is your perception regarding employment time after graduation? Only $16 \%$ replied immediately while 5\% said they may never get any job. However, cumulatively more than $50 \%$ of the respondents said they may get a job less than 6 months. $13 \%$ of the respondents said they anticipate to stay without a job for than a job.

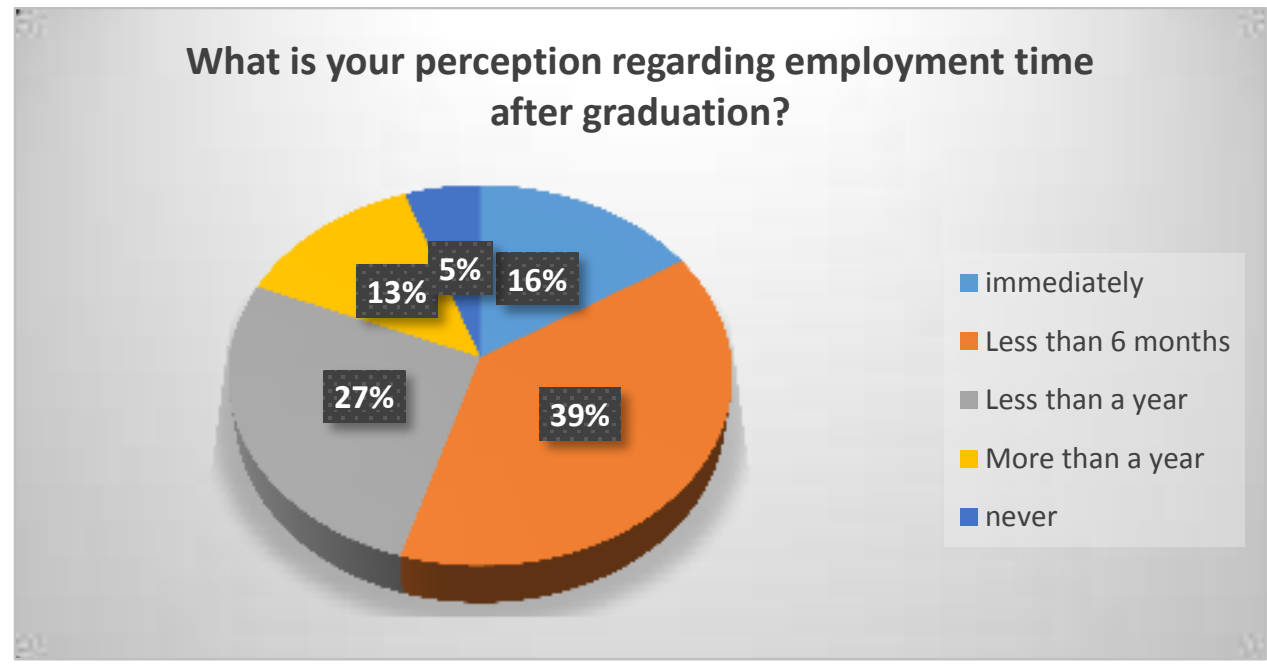

Graph 2: employment time after graduation

Interpretation

According to the responses given by the business students, it is not easy to find a job in Kenya. Some students, though few, said they may never a get a job. This shows how employment opportunities are scarce in Kenya. $84 \%$ of business students say they don't expect to get job opportunity immediately they graduate. This means completing the course does not guarantee job placement. The government should put some measures to reassure university students and work towards job creation.

3. Students opinion towards employers preference

What is your opinion towards future employer's preference? 


\begin{tabular}{|l|l|l|}
\hline Responses & Frequency & Percentage \\
\hline High grades & 30 & 40 \\
\hline confidence & 17 & 23 \\
\hline Good communication skills & 15 & 20 \\
\hline Physical look & 3 & 4 \\
\hline Honesty and integrity & 10 & 13 \\
\hline Total & $\mathbf{7 5}$ & $\mathbf{1 0 0}$ \\
\hline
\end{tabular}

Table 3: opinion on employer preference

Analysis

When the respondents were asked to give their opinions about future employers' preference, $40 \%$ said high grades are important to the employers while $23 \%$ said confidence can get you employment and $20 \%$ said good communication. $4 \%$ of the respondents said having good physical look can land you a job while $13 \%$ were for the opinion that honesty and integrity were paramount for employers.

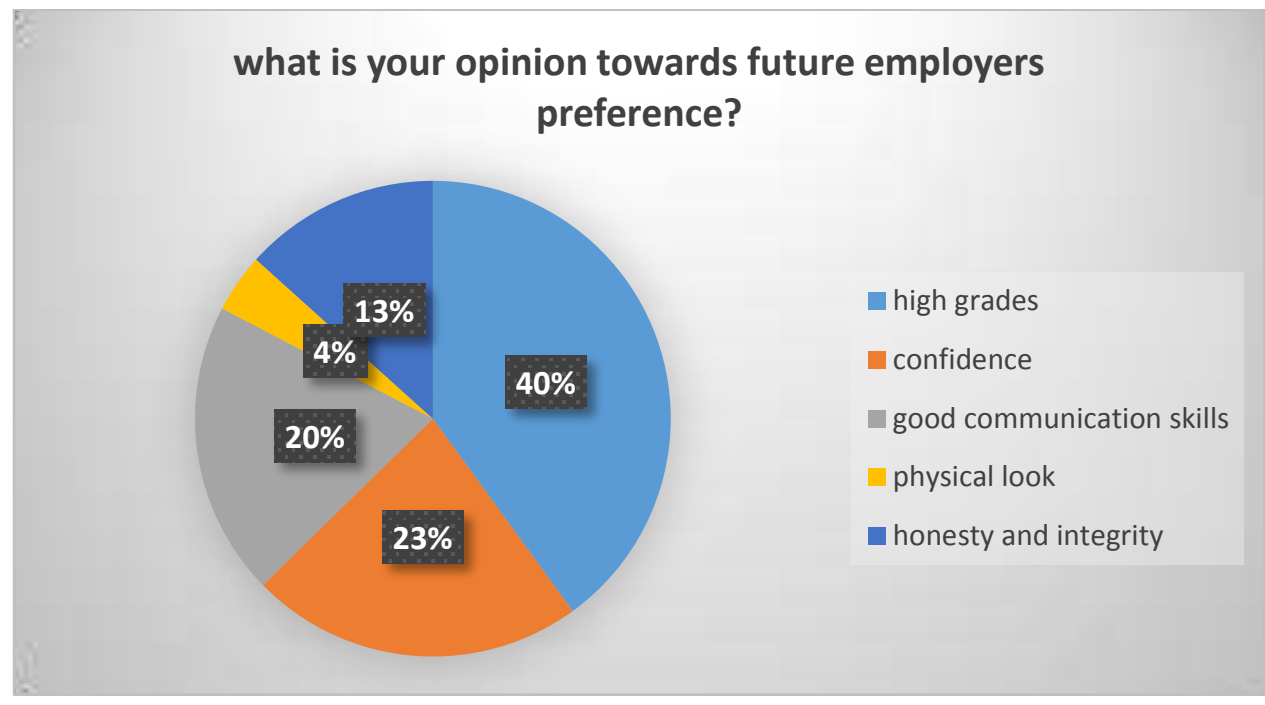

Graph 3: opinion on employer preference

Interpretation

According to business students, getting good grades at the university can secure you a job compared to those who performed poorly. Having confidence in whatever you do was rated high among students also. You need to have good communication skills if you want to get a job with the current crop of employers. It was noted that having good physical looks is not important for employers. As per the responses given, if you score high in your examinations, coupled with good communication skills and confidence then employers are looking for you.

4. Causes of unemployment

Why do you think many business graduates remain unemployed after graduating?

\begin{tabular}{|l|l|l|}
\hline Responses & Frequency & Percentage \\
\hline Few opportunities & 38 & 50 \\
\hline Tribalism and nepotism & 24 & 32 \\
\hline Lack of interest among job seekers & 3 & 4 \\
\hline Lack of enough knowledge and capacity & 2 & 3 \\
\hline Very stiff competition & 8 & 11 \\
\hline
\end{tabular}




\begin{tabular}{|l|l|l|}
\hline Total & 75 & $100 \%$ \\
\hline
\end{tabular}

Table 4: causes of unemployment

Analysis

Respondents were asked to give their views on causes of job opportunities. $50 \%$ of them said its due to lack of few opportunities, $32 \%$ of them said tribalism and nepotism are also major causes of unemployment because the few opportunities available are given to tribesmen and close relatives. $11 \%$ were for the opinion that very stiff competition was the main cause of unemployment.

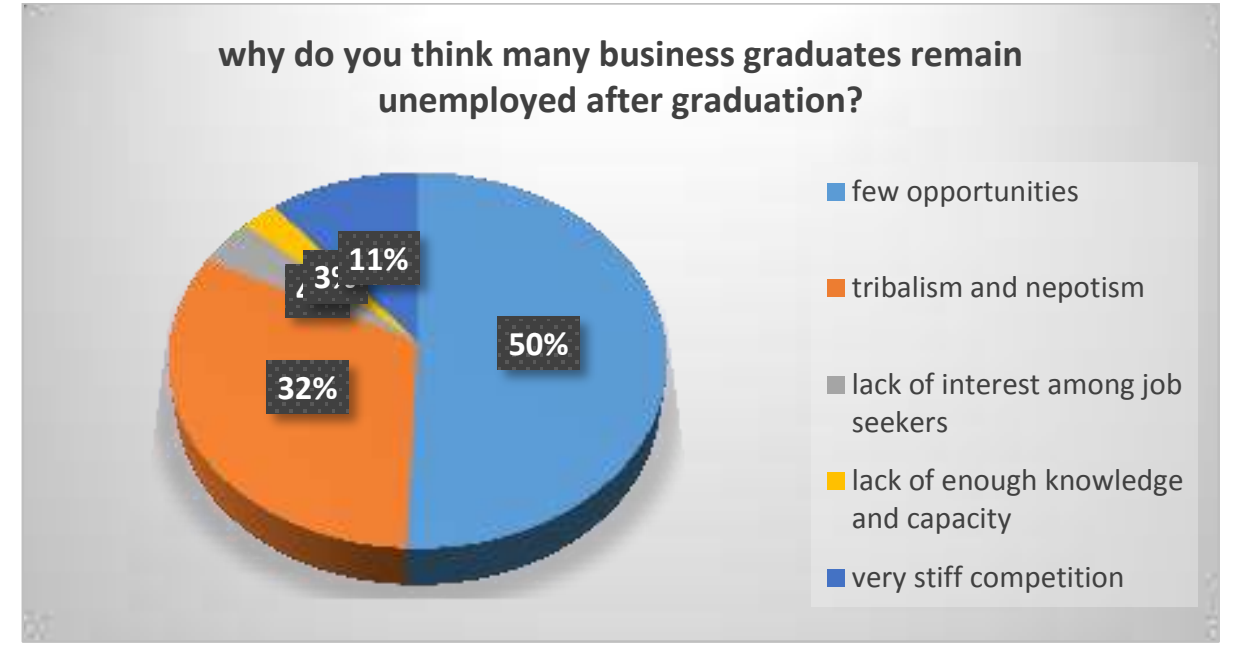

Chart 4: causes of unemployment

The rate of unemployment is high among university graduates in Kenya. According to this research, lack of creating employment opportunities for the youth is the major cause of unemployment. The few opportunities available has created stiff competition which has in turn scaled corruption, nepotism and tribalism. It's only those who are politically correct who are considered for job placement. This has demoralized the youth and the public at large.

5. Engaging in self-employment

Will you engage in self-employment instead of looking for a job?

\begin{tabular}{|l|l|l|}
\hline Responses & Frequency & Percentage \\
\hline Yes & & 24 \\
\hline No & 48 & 64 \\
\hline Don't know & 9 & 12 \\
\hline Total & 75 & 100 \\
\hline
\end{tabular}

Table 5: engaging self-employment

Analysis

When the respondents were presented to the question "Will you engage in self-employment instead of looking for a job?" $64 \%$ of them said they will not engage in self-employment while $24 \%$ of them said they will, where $12 \%$ responded they don't know what to do after completing their studies. 


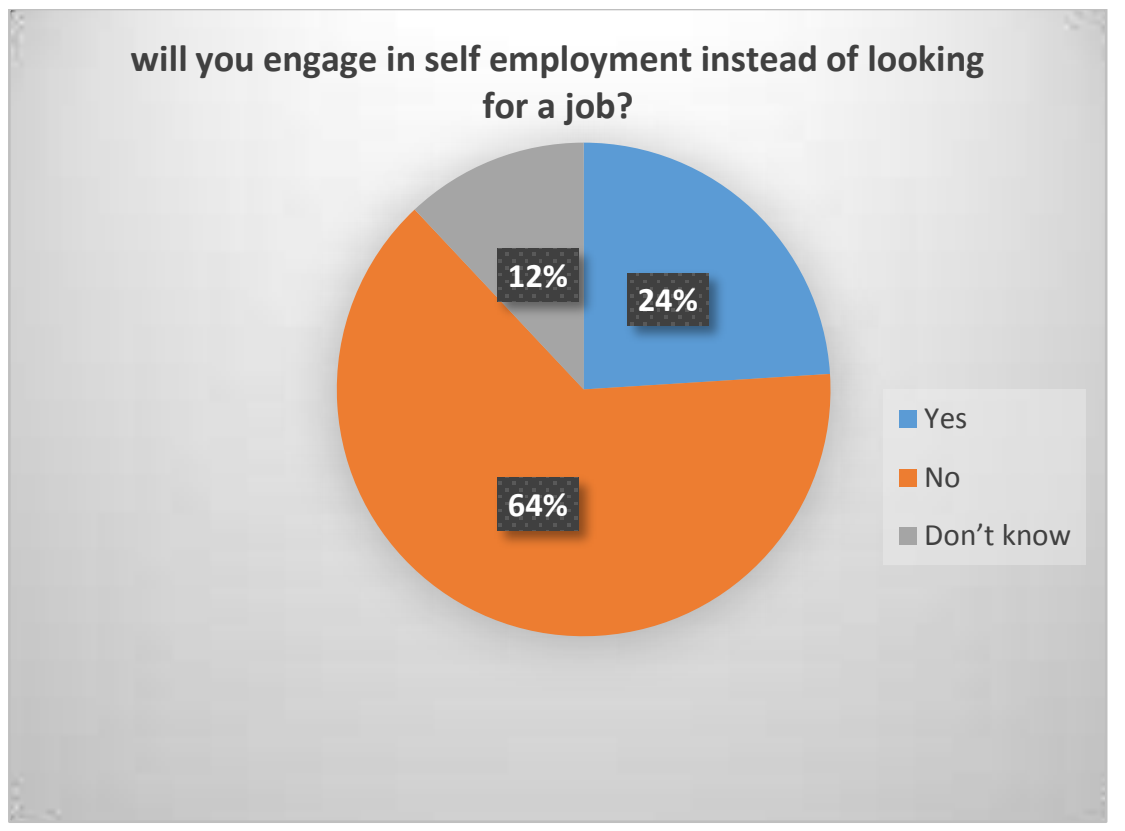

Chart 5: engaging self-employment

\section{Interpretation}

Students prefer to work for others instead of starting their own ventures. Close to two-thirds of the students are prepared to work psychologically for others. This is caused by lack of creating awareness among students. Students prefer white collar jobs thinking that it pays better and more respectable in the society. To tilt the scale students should be informed about the concept of job creation instead of job seeking.

\section{Conclusion}

The youth are the future leaders of any country. They should be invested in heavily by the authorities in place. Proper and relevant training should be given to them. University operations should be modernized in order to impart the much needed knowledge to the students. The perception of business students towards future job market finds that employers have their own preference which should be met in order to upscale productivity. This can only be done if courses offered are specifically streamlined and tailor made to the needs of the market. Courses that were rendered useless should be done away with. Universities should enhance community outreach programs in order to effectively understand various organization needs. This will enhance proper communication between the universities and the industry.

\section{Recommendations}

The research recommends the following;

1. Universities should expose their students to the market by initiating industrial visits and well organized community outreach.

2. Job creation should be encouraged among students. This will lower the pressure of job seeking.

3. Universities should streamline their courses in line with the market demands.

4. Further study ought to be done on the perception of employers on university graduates to understand their needs.

\section{References}

[1] Albaum, G. and R. A. Peterson. 2006. Ethical attitudes of future business leaders - do they vary by gender and religiosity? Business \& Society 3: 300-321.

[2] Alleyne, Ph., D. Devonish, J. Allman, W. Charles-Soverall and A. Y. Marshall. 2010. Measuring ethical perceptions and intentions among undergraduate students in Barbados. The journal of American academy of business 2: 319-326.

[3] Chapman, K. J. and R. A. Lupton. 2004. Academic dishonesty in a global educational market. The international journal of educational management 7: 425-435. 
[4] Chapman, K. J., R. Davis, D. Toy and L. Wright. 2004. Academic integrity in the business school environment: I'll get by with a little help from my friends. Journal of marketing education 3: 236249.

[5] Critteden, V. L., R. C. Hanna and R. A. Peterson. 2009. Business students' attitudes toward unethical bahavior: a multi-country comparison. Market lett. 20: 1-14.

[6] Barat, S. and Spillan, J. 2009. A cross country comparative analysis of students' perceptions of the sales profession: A look at U.S., Peru, and Guatemala. Marketing Management Journal, 19: 52-63.

[7] Bristow, D., Gulati, R., Amyx, D. and Slack, J. 2006. An empirical look at professional selling from a student perspective. Journal of Education for Business, 81: 242-250.

[8] Burnett, M., Pettijohn, C. and Keith, N. 2008. A comparison of the ethical perceptions of prospective personal selling and advertising employees. Marketing Management Journal, 18: 77-83.

[9] Friestad, M. and Wright, P. 1994. The persuasion knowledge model: How people cope with persuasion attempts. Journal of Consumer Research, 21: 1-31.

[10] Hofstede, G. 2012. Dimensions of national cultures. Retrieved from http://geert-hofstede.com, accessed $8 / 5 / 12$

[11] Hecker, D. E. (2005) “Occupational Employment Projections to 2014,” Monthly Labor Review, Vol. 128, No. 11, November, pp. 70-101.

[12] Pedhazur E. J. and Pedhazur-Schmelkin, L. (1991) Measurement, Design and Analysis: An Integrated Approach, Lawrence Erlbaum Associates, Publishers: Hillsdale, New Jersey. US Department of Labor (2007), Occupational Employment Report, Occupation Outlook Quarterly, available at http://www.bls.gov/opub/ooq/2007/fall/art02.pdf.

[13] Walstrom, K. A., Schambach, T.P., Jones, K.T. and Crampton, W.J. (2008) "Why are Students Not Majoring in Information Systems?” Journal of Information Systems Education 